\section{Commentary: Truncal valve intervention in children}

\author{
Michiaki Imamura, $\mathrm{MD}, \mathrm{PhD}$
}

Significant truncal valve regurgitation is a challenging issue for the surgeon. Surgical intervention for moderate truncal valve insufficiency remains controversial. Some neonates tolerate moderate regurgitation and undergo only truncus arteriosus repair without intervention for the truncal valve ${ }^{1}$; however, some patients with moderate regurgitation require intervention even at a small size and younger age. ${ }^{2}$ Of course, severe truncal valve regurgitation requires intervention in a timely manner.

In this issue of the Journal, Naimo and colleagues at Royal Children's Hospital provide an expert technical review of truncal valve repair in children. ${ }^{3}$ They summarize the impact of truncal valve insufficiency on the surgical repair of truncus arteriosus using several reports involving their institution. They review the surgical techniques of truncal valve repair in suturing commissures, resuspension of leaflets, partial resection of leaflets, annuloplasty, leaflet extension, and tricuspidization of a quadricuspid valve. Owing to the large annulus and sinotubular (ST) junction of the truncal valve, annular or ST junction reduction can be achieved by ST junction plication, subcommissural suture, or circular suture annuloplasty. The tricuspidization of a quadricuspid valve is illustrated in 2 cases, complete cusp resection and truncal wall section and cusp resection with cusp approximation. In the truncal valve, even if at the same cusp, some parts looked normal and some parts appeared dysplastic. In this situation, the dysplastic parts of the cusp can be excised, and the normal, pliable parts can be saved and used to restore the new cusp.

Tricuspidization was introduced by Dr Mee in the mid 1990s. ${ }^{4}$ Benefits of this technique include decreasing the truncal valve annulus and ST junction and avoiding touching

From the Division of Congenital Heart Surgery, Texas Children's Hospital, Houston, Tex.

Disclosures: The author reported no conflicts of interest.

The Journal policy requires editors and reviewers to disclose conflicts of interest and to decline handling or reviewing manuscripts for which they may have a conflict of interest. The editors and reviewers of this article have no conflicts of interest.

Received for publication Oct 25, 2020; revisions received Oct 25, 2020; accepted for publication Oct 26, 2020; available ahead of print Nov 5, 2020.

Address for reprints: Michiaki Imamura, MD, PhD, Division of Congenital Heart Surgery, Texas Children's Hospital, 6651 S Main St, Houston, TX 77030 (E-mail: mximamur@texaschildrens.org).

J Thorac Cardiovasc Surg 2021;162:1345

$0022-5223 / \$ 36.00$

Copyright (c) 2020 by The American Association for Thoracic Surgery

https://doi.org/10.1016/j.jtcvs.2020.10.100

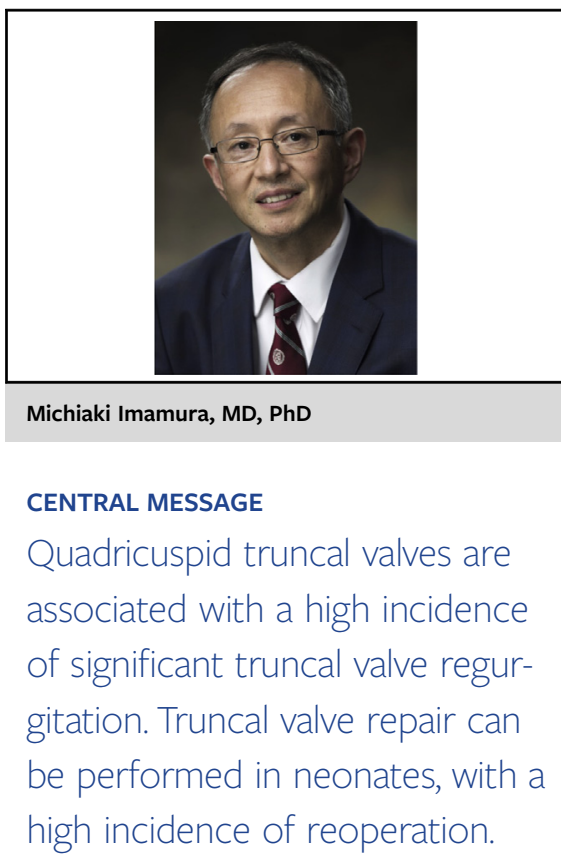

or suturing the cusp itself, which is very fragile and often having myxomatous changes in neonates. This author group previously reported tricuspidization of a intramural coronary artery with coronary ostial stenosis in a neonate with commissure detachment, coronary unroofing, truncal wall and small cusp resection, and truncal wall and cusp approximation. ${ }^{5}$

Many surgeons are hesitant to touch and suture the aortic or truncal valve cusp itself on neonate patients owing to concerns about suture dehiscence. Dr Mee's technique does not require touching the cusp itself. The author previously demonstrated cusp approximation using a continuous 8-0 polypropylene suture and reported excellent results at a 6-month follow-up. Now the surgical team at the Royal Children's Hospital is definitely the leader in this challenging field of truncal valve intervention in the neonate.

\section{References}

1. Henaine R, Azarnoush K, Belli E, Capderou A, Roussin R, Planché C, et al. Fate of the truncal valve in truncus arteriosus. Ann Thorac Surg. 2008;85:172-8.

2. Naimo PS, Fricke TA, d'Udekem Y, Brink J, Weintraub R, Brizard CP, et al Impact of truncal valve surgery on the outcomes of the truncus arteriosus repair. Eur J Cardiothorac Surg. 2018:54:524-31.

3. Naimo PS, Buratto E, Konstantinov IR. Truncal valve repair in children. J Thorac Cardiovasc Surg. 2021;162:1337-42.

4. Imamura M, Drummond-Webb JJ, Sarris GE, Mee RB. Improving early and intermediate results of truncus arteriosus repair: a new technique of truncal valve repair. Ann Thorac Surg. 1999;67:1142-6.

5. Konstantinov IE, Perrier SL, Naimo PS, d'Udekem Y. Neonatal quadricuspid truncal valve repair with left coronary artery unroofing. I Thorac Cardiovasc Surg. 2019;157:710-1. 